\title{
Characterization of casein-derived peptide bioactivity: Differential effects on angiotensin-converting enzyme inhibition and cytokine and nitric oxide production
}

\author{
C. Adams, ${ }^{1}$ F. Sawh, ${ }^{1}$ J. M. Green-Johnson, ${ }^{1}$ (1) H. Jones Taggart, ${ }^{2 *}$ (다 and J. L. Strap ${ }^{1}$ () \\ ${ }^{1}$ Faculty of Science, Ontario Tech University, Oshawa, Canada, L1G 0C5 \\ ${ }^{2}$ Faculty of Health Sciences, Ontario Tech University, Oshawa, Canada, L1G 0C5
}

\begin{abstract}
Lactic acid bacteria (LAB) are used as starter cultures in the production of fermented dairy products and have the potential to confer bioactivity relevant to cardiovascular health, as they possess extensive proteolytic systems that liberate small bioactive peptides from larger milk proteins. Certain casein-derived peptides released by various LAB strains during fermentation have been shown to reduce hypertension and to modulate the immune system. We investigated the growth and peptide production of $2 \mathrm{LAB}$ strains, Lactobacillus helveticus R0389 and Lactocaseibacillus rhamnosus R0011, their immunomodulatory activities, as well as their abilities to inhibit the angiotensin-converting enzyme (ACE). Peptide fractions collected from the cell-free supernatant of both medium-grown and milk fermentation cultures were assessed for ACE-inhibitory activity and their effects on the production of proinflammatory and regulatory cytokines by human THP-1 monocytes. Cultures were grown in medium, with or without supplementation with $0.1 \%$ casein, or in $3.25 \%$ milk fermented with each LAB strain. Casein supplementation increased the growth rate of both LAB strains, and significantly increased ACE-inhibitory activity of peptide fractions collected from both $L$. helveticus R0389 and L. rhamnosus R0011 cultures grown for $12 \mathrm{~h}$. Fermentation peptide fractions of L. rhamnosus R0011 showed comparable ACE-inhibitory activity to known ACE inhibiting peptides Val-Pro-Pro and IlePro-Pro (up to $79 \%$ inhibition) with a significant difference between culture peptide fractions and acidified and nonacidified control fractions collected after $6 \mathrm{~d}$ of fermentation. Many milk and casein-derived peptides reported in previous studies have been identified as part of a larger bioactive fraction. We synthesized a group of these peptides to individually assess both ACE-inhibi-
\end{abstract}

Received November 28, 2019.

Accepted March 16, 2020.

*Corresponding author: Holly.JonesTaggart@OntarioTechU.ca tory and immunomodulatory activity. The known ACE inhibitors Val-Pro-Pro and Ile-Pro-Pro showed similar ACE inhibition to previously published results, while also inducing the production of the regulatory cytokine IL-10 by monocytes in the presence and absence of a proinflammatory stimulant. These synthesized peptides could also induce the production of nitric oxide (NO), a potent vasodilator, in human endothelial cell cultures. Investigating the relationships among these bioactive properties could improve the use of probiotic organisms and their secreted products in the food industry.

Key words: lactobacillus, bioactive peptide, ACE inhibition, antihypertensive, immunomodulatory

\section{INTRODUCTION}

Atherosclerosis, a chronic inflammatory condition, is the leading cause of cardiovascular disease (CVD) worldwide. Endothelial cell dysfunction triggers activation of the immune system through the recruitment of monocytes, T-cells, and dendritic cells, as sources of proinflammatory cytokines, and plays an important role in the pathogenesis of CVD (Galkina and Ley, 2009; Lundberg and Hansson, 2010; Andersson et al., 2010). This inflammatory response eventually leads to narrowing of the artery, decreased blood flow, and increased blood pressure.

Treatment options for atherosclerosis highlight blood pressure reduction through angiotensin-converting enzyme (ACE)-inhibiting drugs. Angiotensin-converting enzyme inhibition prevents formation of angiotensin II and inactivation of bradykinin, thereby facilitating relaxation of the vascular muscle wall to decrease blood pressure (Turner and Hooper, 2002; Unger, 2002). Additionally, nitric oxide (NO), a potent vasoactive agent secreted by endothelial cells in response to blood pressure fluctuations, has been shown to exert various cardioprotective effects such as vasodilation and regulation of platelet aggregation and adhesion (Moore et al., 2010). Endothelial cell generation of NO is an important vasodilatory and antithrombotic mechanism es- 
sential for cardiovascular health. As a dietary strategy to improve cardiovascular outcomes, the consumption of low-fat fermented dairy products has been shown to lower blood pressure and reduce hypertension, decreasing risk factors associated with development of CVD (Lamarche, 2008; Sonestedt et al., 2011; Astrup 2014; Bordoni et al., 2017). The nutritionally fastidious lactic acid bacteria (LAB), used in the production of fermented milk products, have diverse proteolytic systems that generate small peptides from casein (Savijoki et al., 2006) that can have a variety of beneficial bioactive properties, including reducing hypertension and modulating the immune system (Korhonen and Pihlanto, 2006; Tidona et al., 2009; Rodríguez-Figueroa et al., 2012; Chakrabarti and $\mathrm{Wu}, 2016$ ).

Antihypertensive peptides generated by LAB have been widely studied; however, the interaction of these peptides with immune cells is often overlooked. In this study, we assessed the ACE-inhibitory activity of secreted peptide fractions collected from cultures of 2 LAB strains, as well as from milk fermented with each of them. The effect of these secreted peptides on cytokine production by THP-1 monocytes was assessed and compared with that of individually synthesized peptide sequences previously identified from bioactive fractions. Two short peptides, Val-Pro-Pro and Ile-ProPro (VPP and IPP), have previously been reported to induce NO production in cultured human umbilical vein endothelial cells (HUVEC; Hirota et al., 2011) and to increase mucus production in a human intestinal goblet cell model (Giromini et al., 2019). Our study further extends this evaluation of NO production by endothelial cells to include other previously identified casein-derived peptides and compares them all together. Understanding the effects of bioactive peptides on immune cell response and endothelial cell health is crucial for the identification of casein-derived peptides that have cardioprotective and health improvement qualities.

\section{MATERIALS AND METHODS}

\section{Materials}

All reagents used were purchased from Sigma Aldrich Co. (St. Louis, MO) unless otherwise stated.

\section{Bacterial Strains and Cell Culture Growth Conditions}

Both LAB strains used in this study, Lactobacillus helveticus R0389 and Lactocaseibacillus rhamnosus R0011, were provided by Lallemand Health Solutions (Montreal, QC, Canada). Both strains were grown in
Difco de Man, Rogosa, Sharpe (MRS) broth (BD Diagnostic Systems, Sparks, MD) at $37^{\circ} \mathrm{C}$ under agitation (200-220 rpm), unless otherwise stated.

The THP-1 human monocytic cell line (ATCC \#TIB-202) was used for all immunological studies. The THP-1 cells were grown in RPMI 1640 growth medium (supplemented with $10 \%$ fetal bovine serum, $0.05 \mathrm{mg} /$ $\mathrm{mL}$ gentamicin, and $0.05 \mathrm{~m} M \beta$-mercaptoethanol) at $37^{\circ} \mathrm{C}$ with $5 \% \mathrm{CO}_{2}$. Cells were subcultured every 3 to $4 \mathrm{~d}$.

The HUVEC cell line (ATCC \#CRL-1730) was used for all NO liberation studies. The HUVEC were grown in MCBD-131 growth medium (supplemented with $10 \%$ fetal bovine serum, $1 \mathrm{mg} / \mathrm{mL}$ epidermal growth factor, $50 \mu \mathrm{g} / \mathrm{mL}$ hydrocortisone, $10 \mathrm{mM}$ L-glutamine, 10,000 units/mL penicillin, and $10 \mathrm{mg} / \mathrm{mL}$ streptomycin) at $37^{\circ} \mathrm{C}$ with $5 \% \mathrm{CO}_{2}$. Cells were subcultured at $80 \%$ confluence and were used at passage 2 to perform all assays.

\section{Analysis of Growth Rate}

Lactobacillus helveticus R0389 and L. rhamnosus R0011 were grown in MRS or MRS supplemented with $0.1 \%$ (wt/vol) casein or with $0.01 \%$ sodium formate $(\mathrm{NaCOOH})$, and optical density (OD) at $600 \mathrm{~nm}$ $\left(\mathrm{OD}_{600 \mathrm{~nm}}\right)$ was measured every hour for $24 \mathrm{~h}$. Due to the low solubility of casein, a low percentage $(0.01 \%)$ was chosen to allow for growth kinetics to be followed by OD measurement. Growth rate and doubling times were calculated for each strain.

\section{Milk Fermentation}

Cultures of L. helveticus R0389 and L. rhamnosus R0011 grown in MRS broth were used to inoculate locally purchased retail milk $3.25 \%$ (wt/vol of milk fat) homogenized milk. Acidified controls were prepared by adding $0.4 \%$ ( $\mathrm{vol} / \mathrm{vol}$ ) of $\mathrm{D} / \mathrm{L}$-lactic acid to fresh $3.25 \%$ milk. Nonacidified controls consisted of noninoculated $3.25 \%$ milk fermented under identical conditions to inoculated milk samples. All samples and controls were incubated at $37^{\circ} \mathrm{C}$ under agitation (200-220 rpm) for 3 , 4,5 , or $6 \mathrm{~d}$.

\section{Isolation and Collection of Secreted Peptides}

Cultures of L. helveticus R0389 and L. rhamnosus R0011, in MRS medium or in $3.25 \%$ milk, were centrifuged at $3,000 \times g$ for 20 min at room temperature at various time points throughout growth (after 6,12 , and $24 \mathrm{~h}$ for MRS-grown cultures and after 3, 4, 5, and $6 \mathrm{~d}$ for cultures in $3.25 \%$ milk). The cell-free supernatants 
were collected, and proteins and peptides were precipitated from the supernatant solution by the addition of 2 volumes of ice-cold acetone (Hames, 1981). The precipitate was collected by centrifugation at $3,000 \times$ $g$ for $15 \mathrm{~min}$ at $4^{\circ} \mathrm{C}$. Dried protein pellets were resuspended in twice the pellet volume with either deionized $\mathrm{H}_{2} \mathrm{O}$ or protein buffer solution composed of $25 \%$ (vol/ vol) glycerol, $1 \mathrm{~m} M$ EDTA, and $10 \mathrm{~m} M$ Tris- $\mathrm{HCl}$ in $\mathrm{H}_{2} \mathrm{O}$, and filtered using Amicon centrifugal filter units (Millipore, Etobicoke, Canada) with a molecular weight cut-off of either 3 or $10 \mathrm{kDa}$. The filtrate was collected and peptide concentration was measured by Bradford assay (Bradford, 1976) using BSA as a standard.

\section{Synthesized Peptides}

Twelve previously identified, and published, bioactive peptides derived from $\beta$-casein were selected and individually tested for their ACE-inhibitory and immunomodulatory properties (Table 1 ). The 12 peptides included the highly characterized antihypertensive VPP and IPP. The remaining peptides had either been identified as part of a larger bioactive fraction or had not been previously assessed for either their antihypertensive or immunomodulatory properties, or both. All synthesized peptides were obtained from Bio Basic Inc. (Markham, ON, Canada).

\section{ACE Inhibition Assay}

We assessed ACE-inhibitory activity using a method adopted from Cushman and Cheung (1971). In brief, we incubated $200 \mu \mathrm{L}$ of $3.8 \mathrm{~m} M$ hippuryl-L-histidyl-Lleucine buffer substrate in $0.1 \mathrm{M}$ sodium borate buffer with $0.3 M \mathrm{NaCl}(\mathrm{pH} 8.3$ ) with $30 \mu \mathrm{L}$ of $19 \mu \mathrm{g} / \mathrm{mL}$ peptide solution at $37^{\circ} \mathrm{C}$ for $5 \mathrm{~min}$. Twenty microliters of 0.1 $\mathrm{U} / \mathrm{mL} \mathrm{ACE}$ was added to the reaction and incubated at $37^{\circ} \mathrm{C}$ for $30 \mathrm{~min}$. The reaction was stopped with $1 \mathrm{~N}$ $\mathrm{HCl}$ and the liberated hippuric acid was extracted with ethyl acetate. After evaporation of the ethyl acetate, the extracted hippuric acid was dissolved in $1 \mathrm{~mL}$ of deionized $\mathrm{H}_{2} \mathrm{O}$ and measured spectrophotometrically at $228 \mathrm{~nm}$. Percent ACE inhibition was calculated according to the formula: $[(B-A) /(B-C)] \times 100 \%$, where $\mathrm{A}$ is the absorbance in the presence of $\mathrm{ACE}$ and the potential ACE inhibitor, B is the absorbance without inhibitor, and $\mathrm{C}$ is the absorbance without ACE.

\section{Cell Challenge of THP-1 Monocytes}

The THP-1 monocytes in RPMI 1640 medium were challenged with various concentrations of peptide solutions, with or without $125 \mathrm{ng}$ of LPS from Escherichia coli O26:B6 (Sigma Aldrich Co.), for $24 \mathrm{~h}$ in triplicate at $37^{\circ} \mathrm{C}$ with $5 \% \mathrm{CO}_{2}$. Supernatants of challenged cells were collected and stored at $-80^{\circ} \mathrm{C}$ for further analysis.

\section{Cell Viability Assay}

Challenged cells were treated with $15 \mu \mathrm{L}$ of XTT reagent with $125 \mu \mathrm{M} \mathrm{N}$-methyl dibenzopyrazine methyl sulfate and incubated at $37^{\circ} \mathrm{C}$ for $2 \mathrm{~h}$. Absorbance values were recorded at 450 and $650 \mathrm{~nm}$, and the $\Delta \mathrm{OD}_{650-450}$ was recorded.

\section{Measurement of Cytokine Production by ELISA}

The production of the proinflammatory cytokines IL-8 and IL-6, and regulatory cytokine IL-10 was measured using ELISA (R\&D, Minneapolis, MN) as previously described in Jeffrey et al. (2018).

\section{Cell Challenge of HUVEC}

The HUVEC were seeded at a density of 3,500 cells/ $\mathrm{cm}^{2}$ onto 96-well plates. The cells were allowed to adhere and proliferate for $20 \mathrm{~h}$ after the culture was treated with $10 \mu M$ concentrations of each peptide in

Table 1. Synthesized peptide sequences and protein origin

\begin{tabular}{|c|c|c|}
\hline Peptide sequence & Protein origin & Reference \\
\hline$\overline{\mathrm{VPP}}$ & $\beta-\mathrm{CN}(84-86)$ & Nakamura et al., 1995 \\
\hline IPP & $\beta-\mathrm{CN}(74-76)$ & Nakamura et al., 1995 \\
\hline HQPHQPLPPTVMFPPQ & $\beta-\mathrm{CN}(145-160)$ & Tellez et al., 2010 \\
\hline HQPHQPLPPT & $\beta-\mathrm{CN}(145-154)$ & Tellez et al., 2010 \\
\hline WMHQPHQPLPPT & $\beta-\mathrm{CN}(143-154)$ & Tellez et al., 2010 \\
\hline LYQEPVLGPVR & $\beta-\mathrm{CN}(192-202)$ & Tellez et al., 2010 \\
\hline LDQWLCEK & $\beta-\mathrm{CN}(115-122)$ & Tellez et al., 2010 \\
\hline YP & $\alpha_{\mathrm{S} 1} \mathrm{CN}, \beta-\mathrm{CN}, \kappa-\mathrm{CN}$ & Yamamoto et al., 1999 \\
\hline PGPIPN & $\beta-\mathrm{CN}(63-68)$ & Boutrou et al., 2013 \\
\hline FFVAP & $\alpha_{S 1} \mathrm{CN}(23-27)$ & Yamamoto, 1997 \\
\hline KVLPVP & $\beta-\mathrm{CN}(169-174)$ & Maeno et al., 1996 \\
\hline KVLPVPQ & $\beta-\mathrm{CN}(169-175)$ & Maeno et al., 1996 \\
\hline
\end{tabular}




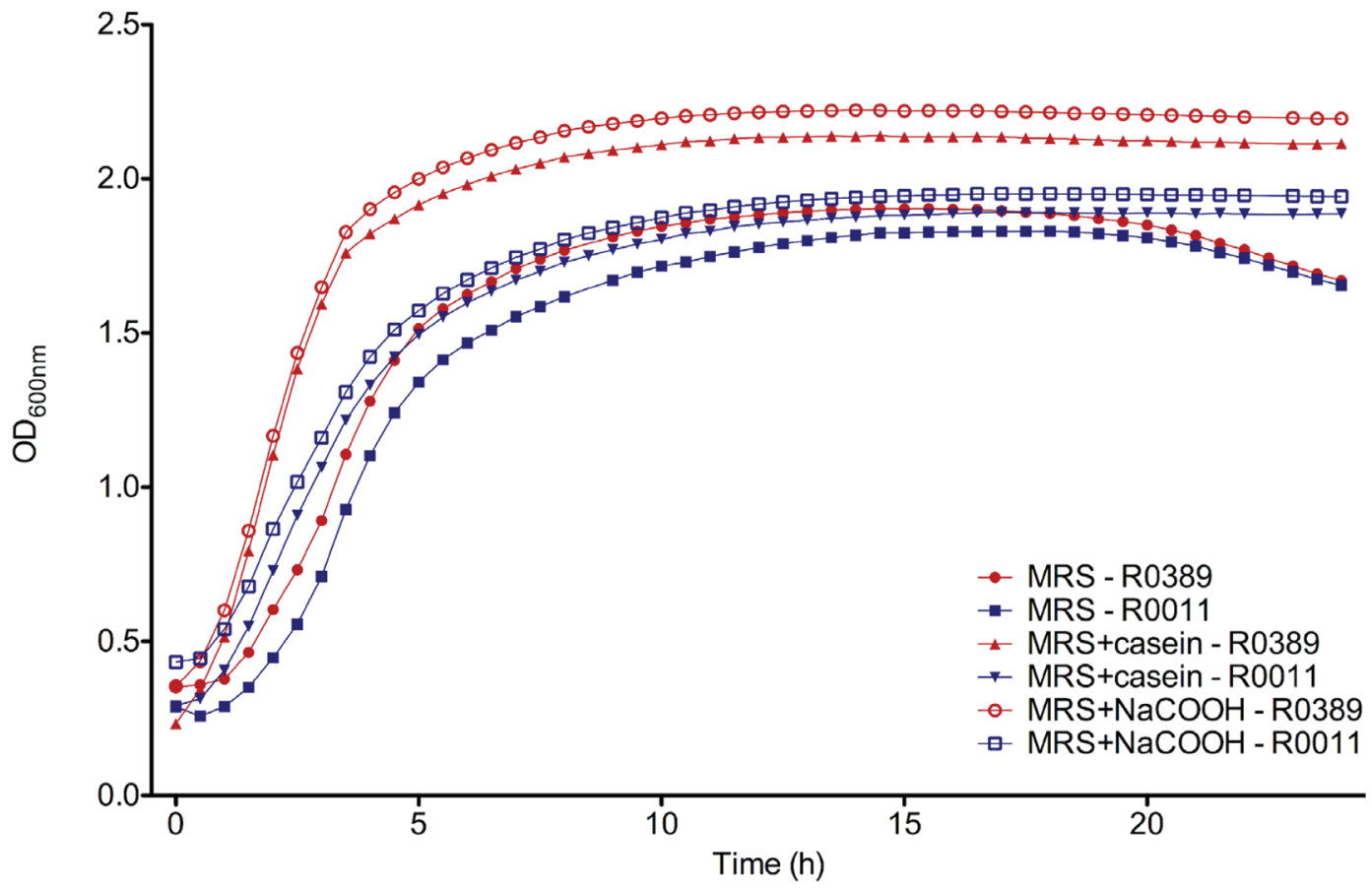

Figure 1. Growth (measured as optical density at $600 \mathrm{~nm}$ ) of Lactobacillus helveticus R0389 and Lactocaseibacillus rhamnosus R0011 in Difco de Man, Rogosa, Sharpe (MRS; BD Diagnostic Systems, Sparks, MD), MRS supplemented with 0.1\% (wt/vol) casein, or MRS supplemented with $0.01 \%$ (wt/vol) sodium formate $(\mathrm{NaCOOH})$ over $24 \mathrm{~h}$. Each data point is the mean of 12 replicate values.

triplicate for $1 \mathrm{~h}$ at $37^{\circ} \mathrm{C}$ with $5 \% \mathrm{CO}_{2}$. Supernatants of treated cells were collected and immediately analyzed for NO production as described by Hirota et al. (2011).

\section{Measurement of NO Production}

The production of NO was measured using the Greiss reaction (Enzo Life Sciences, Farmingdale, NY) according to the manufacturer's instructions.

\section{Statistical Analyses}

Significant differences were assessed by ANOVA with replication or by Student's t-test $(P<0.05)$. All error bars represent standard deviation values.

\section{RESULTS AND DISCUSSION}

\section{Growth Rate Analysis}

Casein is one of the major substrates of the proteolytic systems of LAB used in the fermentation industry. The growth of L. helveticus R0389 and L. rhamnosus R0011 in MRS supplemented with $0.1 \%$ (wt/vol) casein was compared with growth in unsupplemented MRS medium over a 24-h period (Figure 1). Casein supplementation significantly increased the growth rate of both L. helveticus R0389 and L. rhamnosus R0011 $\left(0.567 \pm 0.017\right.$ and $0.484 \pm 0.021 \mathrm{~h}^{-1}$, respectively $)$ compared with MRS-grown cultures $(0.430 \pm 0.010$ and $0.451 \pm 0.021 \mathrm{~h}^{-1}$, respectively; $\left.P<0.05\right)$. Streptococcus thermophilus and Lactobacillus bulgaricus are commonly used as a mixed culture in fermentation. Streptococcus thermophilus provides L. bulgaricus with formic acid, folic acid, and carbon dioxide, which stimulates growth (Sieuwarts et al., 2010). Supplementation of cultures with $0.01 \%$ sodium formate (Figure 1 ) also significantly increased the growth rate of $L$. helveticus R0389 and $L$. rhamnosus R0011 (0.505 \pm 0.022 and $0.383 \pm 0.011 \mathrm{~h}^{-1}$, respectively; $P<0.05)$.

\section{ACE Inhibition}

We measured the ACE-inhibitory activity of the $<10$ $\mathrm{kDa}$ peptide fractions collected from the supernatants of L. helveticus R0389 and L. rhamnosus R0011 cultures grown in MRS and MRS supplemented with $0.1 \%$ casein. The ACE inhibition by the fractions collected from cultures of L. helveticus R0389 and L. rhamnosus R0011 at $12 \mathrm{~h}$ of growth, in casein-supplemented medium, was significantly increased compared with fractions collected from the supernatants of MRS- 


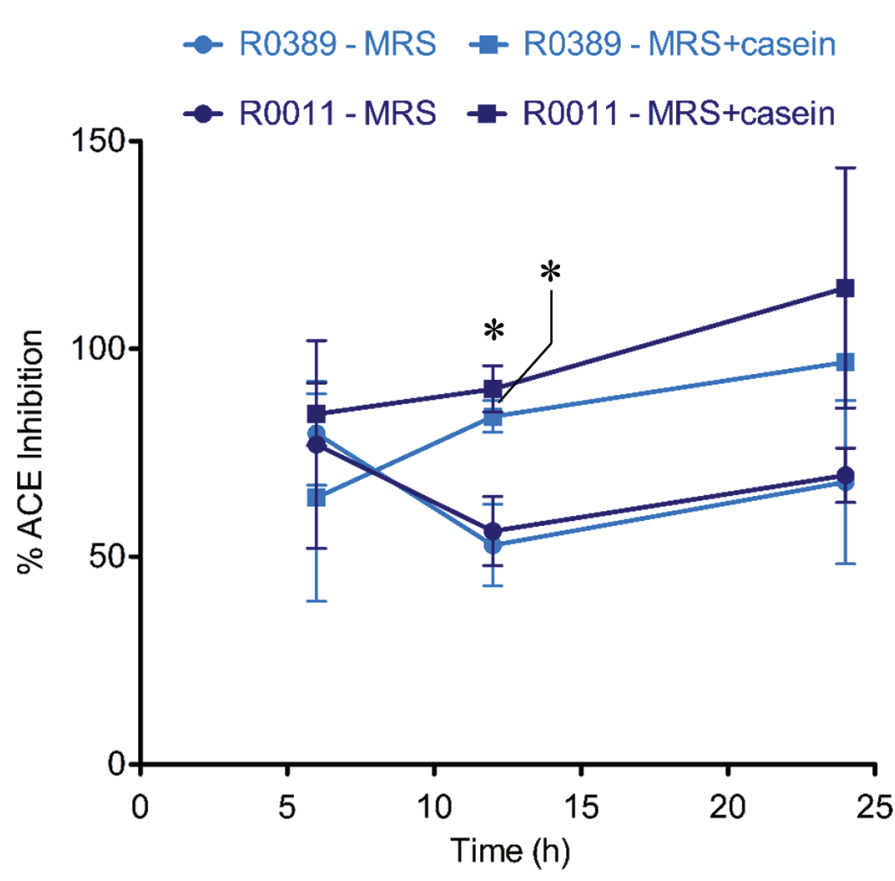

Figure 2. Mean percent angiotensin-converting enzyme (ACE) inhibition $( \pm \mathrm{SD})$ of $<10 \mathrm{kDa}$ peptide fractions $(1 \mu \mathrm{g} / \mathrm{mL})$ isolated from the cell-free supernatant of Lactobacillus helveticus R0389 or Lactocaseibacillus rhamnosus R0011 cultures grown in Difco de Man, Rogosa, Sharpe (MRS; BD Diagnostic Systems, Sparks, MD) or MRS with $0.1 \%$ (wt/vol) casein for $24 \mathrm{~h}(\mathrm{n}=3)$. * Significant difference in ACE inhibition between the casein-supplemented sample and the same strain grown in MRS at the same time point $(P<0.05)$.

grown cultures $(P=0.029$ and 0.004 , respectively; Figure 2). The ACE-inhibitory activity of 12-h MRSgrown culture fractions increased from 53 to $84 \%$ for L. helveticus R0389 fractions, and from 56 to $90 \%$ for fractions from L. rhamnosus R0011 cultures as a result of casein supplementation. Peptide fractions $(<10$ $\mathrm{kDa}$ ) collected from milk fermented with $L$. rhamnosus R0011 for $6 \mathrm{~d}$ had significantly higher ACE-inhibitory activity $(79 \%)$ than the corresponding acidified and nonacidified controls (52 and 41\%, respectively; Figure $3)$. This indicates the presence of one or more bioactive compounds with the ability to inhibit ACE, produced as a result of fermentation with L. rhamnosus R0011, specifically. The ACE inhibition by the ferment fraction was significantly higher than that of the acidified control; therefore, the inhibitory effect was not due to acidification.

Twelve peptides (Table 1), including the known ACE inhibitors VPP and IPP, were synthesized and individually assessed for their ability to inhibit ACE. Both VPP and IPP displayed the highest ACE inhibition $(94 \% \pm 15 \%$ and $68 \% \pm 20 \%$, respectively), with most of the remaining peptides having ACE inhibition of approximately 20 to $40 \%$ (Figure 4).

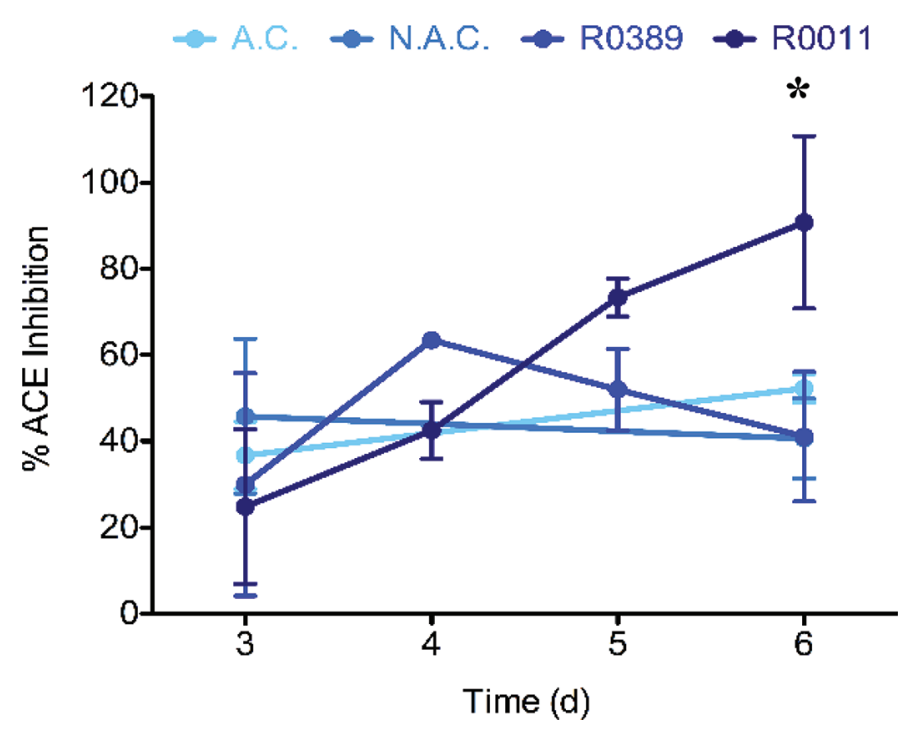

Figure 3. Mean percent angiotensin-converting enzyme (ACE) inhibition $( \pm \mathrm{SD})$ of $<10 \mathrm{kDa}$ peptide fractions $(1 \mu \mathrm{g} / \mathrm{mL})$ in deionized $\mathrm{H}_{2} \mathrm{O}$ isolated from the cell-free supernatant of $3.25 \%$ milk fermented with Lactobacillus helveticus R0389 or Lactocaseibacillus rhamnosus R0011 for 3, 4, 5, or $6 \mathrm{~d}$, or from acidified (A.C.) and nonacidified (N.A.C.) controls $(\mathrm{n}=3)$. ${ }^{*}$ Significant difference between the sample group and both control groups at the same time point $(P<0.05)$.

\section{Effects of Peptides and Fractions on Monocyte Cytokine Production}

The THP-1 monocytes were treated with either individually synthesized peptides or fractions collected from the supernatants of milk fermented with $L$. helveticus R0389 or L. rhamnosus R0011, with and without $125 \mathrm{ng} / \mathrm{mL}$ LPS. In the absence of LPS, the synthesized

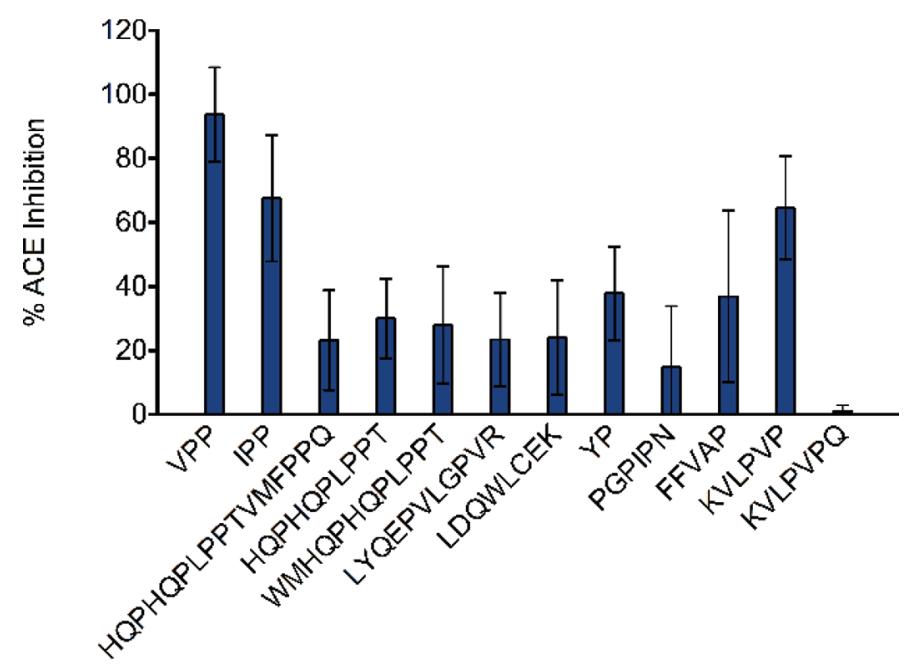

Figure 4. Mean percent angiotensin-converting enzyme (ACE) inhibition $( \pm \mathrm{SD})$ by $1 \mu \mathrm{g} / \mathrm{mL}$ solutions of synthesized peptides $(\mathrm{n}=3)$. 


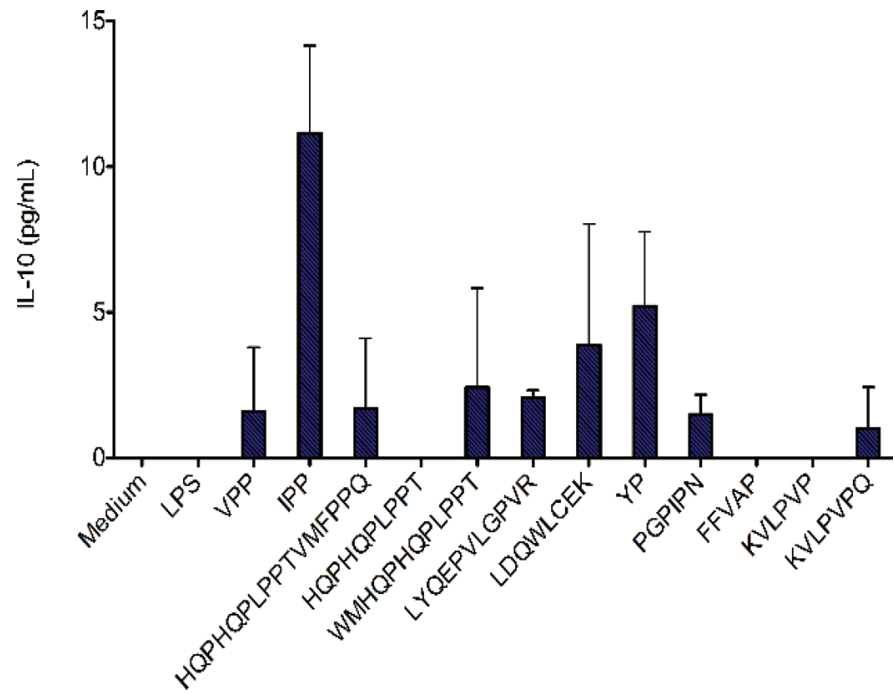

Figure 5. Production of IL-10 ( \pm SD) by THP-1 cells treated for 24 $\mathrm{h}$ with $125 \mathrm{ng} / \mathrm{mL}$ LPS and $1 \mu \mathrm{g} / \mathrm{mL}$ synthesized peptides. Medium $=$ THP- 1 cells cultured in RPMI 1640 medium with $10 \%$ fetal bovine serum; LPS $=$ THP-1 cells stimulated with $125 \mathrm{ng} / \mathrm{mL}$ LPS in RPMI 1640 medium with $10 \%$ fetal bovine serum $(\mathrm{n}=2)$.

peptides and peptide fractions collected from milk ferments did not induce production of the proinflammatory cytokines IL- 8 and IL- 6 by the THP-1 cells, nor reduce LPS-induced production of IL-8 (data not shown). Viability of THP-1 cells remained above $80 \%$ for all treatments. However, certain ferment peptide fractions and individually synthesized peptides induced production of the regulatory cytokine IL-10, even in the presence of LPS (Figure 5). The THP-1 cells treated with IPP $(1 \mu \mathrm{g} / \mathrm{mL})$ and LPS produced the highest concentrations of IL-10 $(11.15 \pm 3.01 \mathrm{pg} / \mathrm{mL})$.

\section{Endothelial Cell Response}

The 12 peptides (Table 1), including VPP and IPP, were synthesized and individually assessed for their ability to induce NO production from cultured HUVECs. Both VPP and IPP displayed the highest NO production $(21.4 \pm 10.8$ and $17.4 \pm 5.9 \mu \mathrm{mol} / \mathrm{L}$, respectively) with most of the remaining peptides having total average measurable NO production ranging from 12 to $20 \mu \mathrm{mol} / \mathrm{L} \pm 3.7$ to $9.8 \mu \mathrm{mol} / \mathrm{L}$ (Figure 6). Concentrations of peptides in medium were at a final concentration of $10 \mu \mathrm{mol} / \mathrm{L}$, as suggested by previously reported $\mathrm{IC}_{50}$ (half-maximal inhibitory concentration) values for ACE inhibition (FitzGerald and Meisel, 2000) and NO stimulation (Hirota et al., 2011).

Few studies have investigated the link between the antihypertensive properties of casein-derived peptides and their effects on the immune system. In this study, we investigated the growth of $2 \mathrm{LAB}$ strains, $L$. helveti- cus R0389 and L. rhamnosus R0011, in medium with or without supplementation with $0.1 \%$ casein or in $3.25 \%$ milk fermented with each strain. Under each of these growth conditions, we assessed the resultant peptide fractions for immunomodulatory activity and the ability to inhibit ACE. We were particularly interested in studying the bioactivity of whole peptide fractions, as it would more closely represent consumption of a fermented dairy product compared with pure, isolated peptides. However, although fermented dairy bioactivity may reflect the combined effects of bioactive components in the milk matrix (Burgain et al., 2014), many milk- and casein-derived peptides reported in previous studies have been identified as part of larger bioactive fractions. Therefore, it was of interest to compare the bioactivities of LAB-derived fractions to the bioactivity of single peptides. Because identifying individual peptides within the bioactive fractions was beyond the scope of this project, we chose to synthesize a group of previously identified peptides to individually assess their ACE-inhibitory and immunomodulatory activities, and to compare these activities with the bioactive fractions generated by the LAB strains.

We observed an increase in growth rate of $L$. helveticus R0389 and L. rhamnosus R0011 cultures when supplemented with $0.1 \%$ casein. Lactobacilli are nutritionally fastidious organisms, often requiring exogenous nitrogen sources to obtain the amino acids required for growth (Savijoki et al., 2006). In protein-rich environ-

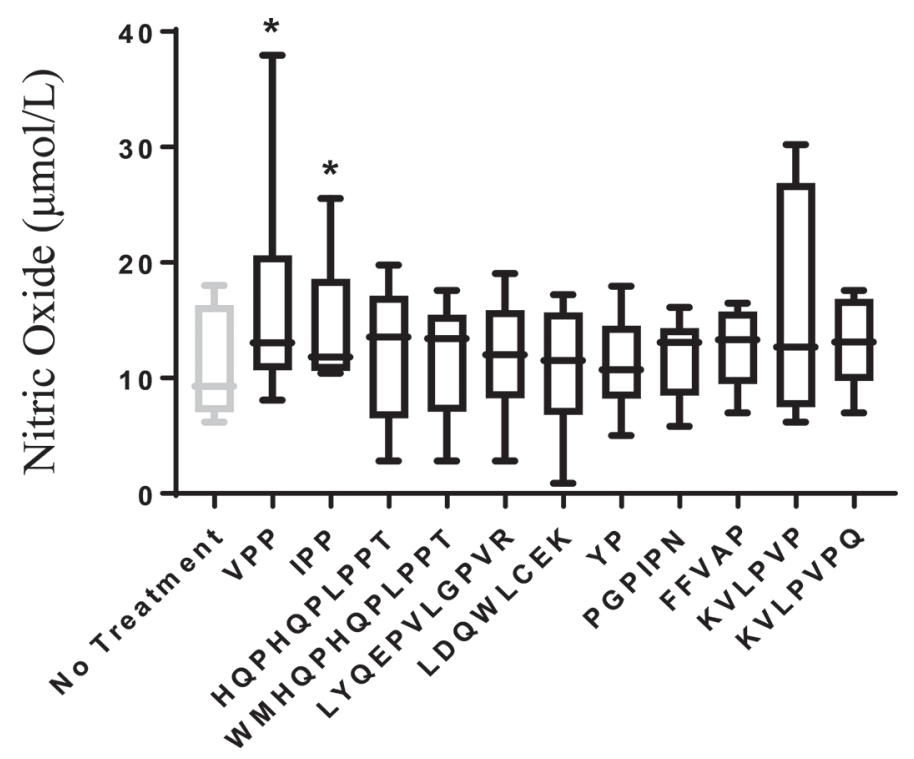

Figure 6. Nitric oxide liberation $(\mu \mathrm{mol} / \mathrm{L})$ measured from human umbilical vein endothelial cells treated with $10 \mu M$ peptide fractions for $1 \mathrm{~h}$ in MCDB-131 medium 18 to $24 \mathrm{~h}$ after cell seeding $(\mathrm{n}=6)$. The plot shows a box (data quartiles 1-3), line (mean), and whiskers (lowest and highest data values). *Significant difference in NO concentration between peptides $(P<0.05)$. 
ments, where concentrations of peptides and individual amino acids are low, lactobacilli must rely on their extensive proteolytic systems to obtain the essential amino acids required for growth. These proteolytic systems include one or multiple cell-enveloped proteinases, peptide transport systems, and intracellular peptidases (Savijoki et al., 2006). Gene expression analysis of various lactobacilli species by Smeianov et al. (2007) and Hebert et al. (2008) showed upregulation of genes encoding proteolytic enzymes during growth in proteinrich environments such as milk, whereas the addition of peptides or casein hydrolysates inhibited synthesis and activity of cell-enveloped proteinases. Increased proteolytic activity by $L$. helveticus R0389 and $L$. rhamnosus R0011 upon casein supplementation would increase the concentration of free peptides in culture supernatants. This explains the observed enhancement of ACE-inhibitory activity of fractions collected from casein-supplemented culture supernatants after $12 \mathrm{~h}$ of growth. Peptides produced during growth in both MRS and casein-supplemented MRS displayed similar ACE inhibition when collected after $6 \mathrm{~h}$ of growth. However, casein supplementation increased proteolytic activity, leading to sustained peptide production from fractions collected after $12 \mathrm{~h}$. This resulted in much higher ACE inhibition compared with fractions from MRS-grown cultures. After $6 \mathrm{~h}, \mathrm{ACE}$ inhibition by fractions collected from MRS-grown cultures immediately began to decrease, likely due to the further breakdown of any remaining peptides into individual amino acids.

Fractions were also collected from whole milk, which contains approximately $29.5 \mathrm{~g} / \mathrm{L}$ casein (Miller et al., 2006). Caseins, as well as other milk proteins, are the predominant nitrogen source in milk for these fastidious LAB during fermentation (Christensen and Steele, 2003). Peptide fractions collected from milk fermented with L. rhamnosus R0011 for 6 d exhibited significantly higher ACE inhibition activity than the corresponding controls. Interestingly, even though it is thought to possess a more extensive proteolytic system (Yamamoto et al., 1993; Beganovic et al., 2013), fractions derived from L. helveticus R0389 ferments did not exhibit ACE inhibition; the observed activity was similar to that of controls. Perhaps proteolysis by the L. helveticus strain is more rapid; larger proteins and peptides would be quickly degraded into individual amino acids, leaving few free peptides in the growth medium. This corresponds to the rapid decrease in ACE inhibition observed in MRS-grown L. helveticus R0389 cultures. However, when compared with the percent ACE inhibition by VPP, the inhibitory activity of peptide fractions collected from the 4-, 5-, and 6-d ferments of $L$. helveticus R0389 and from the 5- and 6-d ferments of L. rhamnosus R0011 were not significantly different.
When compared with that of IPP, the ACE inhibition of peptide fractions collected from ferments of both strains at each of the time points were not significantly different. Further filtration of ferment fractions to retain peptides $<3 \mathrm{kDa}$ resulted in lower $\mathrm{ACE}$ inhibition, suggesting components between 3 and $10 \mathrm{kDa}$, produced within the first $6 \mathrm{~d}$ of fermentation, have the highest bioactivity. If fermentation time were increased, we might observe an increased concentration of small $(<3 \mathrm{kDa})$ peptides resulting in reduced $\mathrm{ACE}$ inhibition at those longer ferment times.

To further address potential mechanisms of bioactivity in the peptide fractions, casein-derived peptides were selected based on literature searches of previously identified bioactive peptides that had not been previously assessed for their antihypertensive or immunomodulatory properties. As expected, VPP and IPP showed the highest percent ACE inhibition. The hexapeptide (KVLPVP) identified by Maeno et al. (1996) showed the next highest percent ACE inhibition. Similar to results previously observed in other studies, peptides containing a C-terminal proline residue (VPP, IPP, YP, FFVAP, and KVLPVP) showed the highest ACE inhibition (Cheung et al., 1980; FitzGerald and Meisel, 2000; Mizuno et al., 2004; Rodríguez-Figueroa et al., 2012) suggesting that the $\mathrm{C}$-terminal proline residue might provide important structural characteristics responsible for the increased ACE inhibition by these peptides. Bioactive peptides containing proline residues are typically more resistant to proteolysis (Mizuno et al., 2004). Both of these characteristics are important factors that influence the bioavailability and bioactivity of orally administered peptides in vivo.

Atherosclerosis is an inflammatory disease, and we are now beginning to better understand the role of the immune system in the progression of this disease and the connections between the immune system and hypertension (Drummond et al., 2019). Characterizing the multiple bioactive properties of milk ferment-derived peptides, including their effects on the immune system and at the endothelial level, could improve our understanding of the mechanisms responsible for the potential health effects of fermented dairy foods in vivo. Varied immunomodulatory activities of milk- and casein-derived bioactive peptides have been reported, including effects on lymphocyte proliferation, cytokine production, and monocyte adhesion to endothelial cells (Sütas et al., 1996a,b; Kayser and Meisel, 1996; Marcone et al., 2015; Santiago-López et al., 2016; Udenigwe and Aluko, 2012b). Effects on monocytes are of particular interest because they are one of the first inflammatory cells to respond to endothelial damage caused by oxidized cholesterol (Lundberg and Hansson, 2010). They play a role in the progression of atherosclerosis 
through lipid retention, activation through toll-like receptors and the subsequent production of proinflammatory cytokines (Galkina and Ley, 2009). Activation of the immune system plays a role in the pathogenesis of atherosclerosis; therefore, reduction in proinflammatory activity has the potential to reduce the risk and progression of this disease.

In this study, ferment fractions and synthesized peptides did not significantly reduce LPS-induced production of IL-8 by THP-1 cells. However, they did not induce significant levels of IL- 8 production, or of another proinflammatory cytokine, IL-6, in the absence of LPS. This indicates that, without existing inflammatory stimuli, these synthesized peptides and peptides within the milk ferment fractions could not induce proinflammatory activity through the production of IL-8 or IL-6. Interestingly, certain $\beta$-casein-derived peptides from fermented milk can induce RAW 264.7 macrophages to produce the proinflammatory cytokines IL8 , tumor necrosis factor- $\alpha$ ( $\mathbf{T N F} \boldsymbol{\alpha})$, and IL-1 $\beta$, and increase production of these nuclear factor kappa-B (NFkB)-regulated cytokines further in the presence of LPS (Tellez et al., 2010). However, other milk-, casein-, or whey-derived peptides inhibit the expression of IL-1 $\beta$ and TNF $\alpha$ by RAW 264.7 macrophages, and inhibit NFKB-mediated signaling, as determined using an NFkB-reporter system (Malinowski et al., 2014; Ma et al., 2016). Yogurt-derived peptides can downregulate the expression of the proinflammatory cytokine IL-12 and the regulatory IL-1 receptor antagonist (IL-1RA), in addition to inducible nitric oxide synthase (iNOS) expression by ovine macrophages and neutrophils, but their effects on other cytokines differ between these cell types, including differential effects on expression of IL$1 \beta$ and the regulatory cytokine transforming growth factor $\beta$ (TGF $\beta$ ) (Theodorou and Politis, 2016). These findings illustrate the varied immunomodulatory activities of different milk-derived peptides, suggesting distinct mechanisms of action, even at the macrophage level, and differential effects between target cell types.

Marcone et al. (2015) observed that milk-derived peptides could reduce the production of the proinflammatory cytokines macrophage chemoattractant protein-1 (MCP-1) and IL-8 by endothelial cells, an effect attributed to peroxisome proliferator-activated receptorgamma (PPAR $\gamma$ )-mediated inhibition of NFkB-induced gene transcription (Marcone et al., 2015). They also observed a decrease in the expression of several adhesion molecules, resulting in decreased monocyte-endothelial cell adhesion. Wagar et al. (2009) observed reduction in TNFo-induced IL-8 production by intestinal epithelial cells when these cells were pre-treated with fermented milk preparations. We noticed no difference in cytokine production when THP-1 monocytes were pre-treated with peptide solutions compared with those co-administered with the inflammatory stimulant. Notably, most of the synthesized peptides used in this study induced production of the regulatory cytokine IL-10 by THP-1 monocytes. Previous research shows that IL-10 can greatly influence the inflammatory process within atherosclerotic lesions by regulating the activity of macrophages and T-cells, and through suppression of IL-12 production (Mallat et al., 1999; Wells, 2011). Therefore, induction of IL-10 production is often used as an indication of the regulatory or anti-inflammatory properties of probiotics or bioactive peptides (Wells, 2011). Although effects on monocytes were only assessed in vitro, Foligne et al. (2007) provided evidence that immune profiles observed in vitro (especially those involving IL-10 and IL-12) can predict immunomodulatory properties in vivo.

Casein-derived bioactive peptides have shown effects on the cardiovascular system through a reduction in blood pressure in mildly hypertensive adults (Mizuno et al., 2005; Akazawa et al., 2018), attenuation of atherosclerosis development in a mouse model (Nakamura et al., 2013), and reduced arterial damage in a rat model (Nonaka et al., 2014). The various proposed actions of bioactive peptides on endothelial functions have been reviewed elsewhere (Chakrabarti and $\mathrm{Wu}, 2016$ ). Endothelial cell-derived NO acts as a signal molecule for vascular muscle relaxation, and its bioavailability is closely linked to vascular health. Nitric oxide is a gas that is produced in endothelial cells through the metabolic conversion of L-arginine to L-citrulline catalyzed by the endothelium-specific enzyme eNOS, the regulation of which has various mediators (Cockcroft, 2005). Hirota et al. (2011) describe VPP- and IPP-induced NO release by HUVEC in culture, as well as their actions on the ex vivo relaxation of rat aortic rings. A comprehensive comparison of the ability of synthesized casein-derived peptides to induce NO (Figure 6) reveals that VPP and IPP are the strongest activators of this mechanism, with other peptides with a C-terminal proline showing similar activation trends. As discussed above, proline is structurally unique. Because proline plays an important role in ligand binding, particularly relevant to intracellular signaling (Kay et al., 2000), peptides with C-terminal prolines are hypothesized to indirectly upregulate eNOS through cell signaling, or exert their NO stimulating effect via the increased bradykinin bioavailability through ACE pathway blockade. A separate mechanism may be used by peptides containing a C-terminal arginine (LYQEPVLGPVR; Tellez et al., 2010) whereby arginine contributes to the generation of NO through its metabolic conversion to citrulline. Interestingly, flaxseed protein hydrolysate containing arginine-rich peptides has also been shown to exert a 
blood-pressure-reducing effect, likely due to this mechanism (Udenigwe and Aluko, 2012a). This points toward potential synergistic mechanisms whereby multiple bioactive peptides act in an additive cardioprotective manner that should be further explored.

\section{CONCLUSIONS}

Current evidence suggests a role for dietary fermented dairy products in promoting cardiovascular health, but many questions still surround the potential mechanisms of action. In this study, peptide fractions were isolated from milk fermented with 2 strains of LAB that showed comparable ACE-inhibitory properties to the known inhibitory peptides VPP and IPP. We report the ACEinhibitory activities of selected synthesized peptides along with their effects on cytokine production by THP-1 monocytes and on NO production by human endothelial cells. Synthesized peptides could induce the production of IL-10 in the presence of an inflammatory stimulant, demonstrating the regulatory bioactivity of these peptides at the monocyte level. Endothelial cells treated with bioactive peptides in culture for $1 \mathrm{~h}$ showed a NO production level consistent with those reported for the tripeptides VPP and IPP. This study adds to the current body of knowledge needed to improve the use of fermented dairy products as functional foods and of probiotics in commercially available dietary products that could contribute to prevention and treatment of a variety of chronic inflammatory diseases such as atherosclerosis.

\section{ACKNOWLEDGMENTS}

This work was supported by funding provided by Natural Sciences and Engineering Research Council Collaborative Research and Development (ON, Canada) and the Dairy Farmers of Canada (QC, Canada). We thank Lallemand Health Solutions (QC, Canada) for supplying the bacteria used in this study, and Thomas A. Tompkins (Rosell Institute for Microbiome and Probiotics, QC, Canada) for valuable insight and discussion. The authors have not stated any conflicts of interest.

\section{REFERENCES}

Akazawa, N., A. Hamasaki, K. Tanahashi, K. Kosaki, T. Yoshikawa, K. Myoenzono, and S. Maeda. 2018. Lactotripeptide ingestion increases cerebral blood flow velocity in middle-aged and older adults. Nutr. Res. 53:61-66. https://doi.org/10.1016/j.nutres.2018 .03 .009 .

Andersson, J., P. Libby, and G. K. Hansson. 2010. Adaptive immunity and atherosclerosis. Clin. Immunol. 134:33-46. https://doi.org/10 .1016/j.clim.2009.07.002.
Astrup, A. 2014. Yogurt and dairy product consumption to prevent cardiometabolic diseases: Epidemiologic and experimental studies. Am. J. Clin. Nutr. 99:1235S-1242S. https://doi.org/10.3945/ajcn .113 .073015 .

Beganović, J., B. Kos, A. Leboš Pavunc, K. Uroić, P. Džidara, and J. Šsušković . 2013. Proteolytic activity of probiotic strain Lactobacillus helveticus M92. Anaerobe 20:58-64. https://doi.org/10.1016/j .anaerobe.2013.02.004.

Bordoni, A., F. Danesi, D. Dardevet, D. Dupont, A. S. Fernandez, D. Gille, C. Nunes Dos Santos, P. Pinto, R. Re, D. Rémond, D. R. Shahar, and G. Vergères. 2017. Dairy products and inflammation: A review of the clinical evidence. Crit. Rev. Food Sci. Nutr. 57:2497-2525. https://doi.org/10.1080/10408398.2014.967385.

Boutrou, R., C. Gaudichon, D. Dupont, J. Jardin, G. Airinei, A. Marsset-Baglieri, R. Benamouzig, D. Tomé, and J. Leonil. 2013. Sequential release of milk protein-derived bioactive peptides in the jejunum in healthy humans. Am. J. Clin. Nutr. 97:1314-1323. https://doi.org/10.3945/ajcn.112.055202.

Bradford, M. M. 1976. A rapid and sensitive method for the quantitation of microgram quantities of protein utilizing the principal of protein-dye binding. Anal. Biochem. 72:248-254. https://doi.org/ 10.1016/0003-2697(76)90527-3.

Burgain, J., J. Scher, G. Francius, F. Borges, M. Corgneau, A. M. Revol-Junelles, C. Cailliez-Grimal, and C. Gaiani. 2014. Lactic acid bacteria in dairy food: Surface characterization and interactions with food matrix components. Adv. Colloid Interface Sci. 213:21-35. https://doi.org/10.1016/j.cis.2014.09.005.

Chakrabarti, S., and J. Wu. 2016. Bioactive peptides on endothelial function. Food Sci. Hum. Wellness 5:1-7. https://doi.org/10.1016/ j.fshw.2015.11.004.

Cheung, H. S., F. L. Wang, M. A. Ondetti, E. F. Sabo, and D. W. Cushman. 1980. Binding of peptide substrates and inhibitors of angiotensin-converting enzyme. Importance of the $\mathrm{COOH}$-terminal dipeptide sequence. J. Biol. Chem. 255:401-407.

Christensen, J. E., and J. L. Steele. 2003. Impaired growth rates in milk of Lactobacillus helveticus peptidase mutants can be overcome by use of amino acid supplements. J. Bacteriol. 185:3297-3306. https://doi.org/10.1128/JB.185.11.3297-3306.2003.

Cockcroft, J. R. 2005. Exploring vascular benefits of endothelium derived nitric oxide. Am. J. Hypertens. 18:177S-183S. https://doi .org/10.1016/j.amjhyper.2005.09.001.

Cushman, D. W., and H. S. Cheung. 1971. Spectrophotometric assay and properties of the angiotensin-converting enzyme of rabbit lung. Biochem. Pharmacol. 20:1637-1648. https://doi.org/10 .1016/0006-2952(71)90292-9.

Drummond, G. R., A. Vinh, T. J. Guzik, and C. G. Sobey. 2019. Immune mechanisms of hypertension. Nat. Rev. Immunol. 19:517532. https://doi.org/10.1038/s41577-019-0160-5.

FitzGerald, R. J., and H. Meisel. 2000. Milk protein-derived peptide inhibitors of angiotensin-I converting enzyme. Br. J. Nutr. 84(Suppl. 1):S33-S37. https://doi.org/10.1017/S0007114500002221.

Foligne, B., S. Nutten, C. Grangette, V. Dennin, D. Goudercourt, S. Poiret, J. Dewulf, D. Brassart, A. Mercenier, and B. Pot. 2007. Correlation between in vitro and in vivo immunomodulatory properties of lactic acid bacteria. World J. Gastroenterol. 13:236-243. https://doi.org/10.3748/wjg.v13.i2.236.

Galkina, E., and K. Ley. 2009. Immune and inflammatory mechanisms of atherosclerosis. Annu. Rev. Immunol. 27:165-197. https://doi .org/10.1146/annurev.immunol.021908.132620.

Giromini, C., J. A. Lovegrove, D. I. Givens, R. Rebucci, L. Pinotti, E. Maffioli, G. Tedeschi, T. S. Sundaram, and A. Baldi. 2019. In vitro-digested milk proteins: Evaluation of angiotensin-1-converting enzyme inhibitory and antioxidant activities, peptidomic profile, and mucin gene expression in HT29-MTX cells. J. Dairy Sci. 102:10760-10771. https://doi.org/10.3168/jds.2019-16833.

Hames, B. D. 1981. An introduction to polyacrylamide gel electrophoresis. Pages 1-86 in Gel Electrophoresis of Proteins: A Practical Approach. B. D. Hames and D. Rickwood, ed. IRL Press Ltd., Oxford, UK

Hebert, E. M., G. Mamone, G. Picariello, R. R. Raya, G. Savoy, P. Ferranti, and F. Addeo. 2008. Characterization of pattern of $\alpha_{s 1^{-}}$ 
and $\beta$-casein breakdown and release of a bioactive peptide by a cell envelope proteinase from Lactobacillus delbrueckii ssp. Lactis CRL 581. Appl. Environ. Microbiol. 74:3682-3689. https://doi.org/10 .1128/AEM.00247-08.

Hirota, T., A. Nonaka, A. Matsushita, N. Uchida, K. Ohki, A. Asakura, and M. Kitakaze. 2011. Milk casein-derived tripeptides, VPP and IPP induced NO production in cultured endothelial cells and endothelium-dependent relaxation of isolated aortic ring. Heart Vessels 26:549-556. https://doi.org/10.1007/s00380-010-0096-y.

Jeffrey, M. P., J. L. Strap, H. Jones Taggart, and J. M. Green-Johnson. 2018. Suppression of intestinal epithelial cell chemokine production by Lactobacillus rhamnosus R0011and Lactobacillus helveticus R0389 is mediated by secreted bioactive molecules. Front. Immunol. 9:2639. https://doi.org/10.3389/fimmu.2018.02639.

Kay, B. K., M. P. Williamson, and M. Sudol. 2000. The importance of being proline: The interaction of proline-rich motifs in signaling proteins with their cognate domains. FASEB J. 14:231-241. https: //doi.org/10.1096/fasebj.14.2.231.

Kayser, H., and H. Meisel. 1996. Stimulation of human peripheral blood lymphocytes by bioactive peptides derived from bovine milk proteins. FEBS Lett. 383:18-20. https://doi.org/10.1016/0014 $-5793(96) 00207-4$.

Korhonen, H., and A. Pihlanto. 2006. Bioactive peptides: Production and functionality. Int. Dairy J. 16:945-960. https://doi.org/10 $.1016 /$ j.idairyj.2005.10.012.

Lamarche, B. 2008. Review of the effect of dairy products on non-lipid risk factors for cardiovascular disease. J. Am. Coll. Nutr. 27:741S746S. https://doi.org/10.1080/07315724.2008.10719752.

Lundberg, A. M., and G. K. Hansson. 2010. Innate immune signals in atherosclerosis. Clin. Immunol. 134:5-24. https://doi.org/10.1016/ j.clim.2009.07.016.

Ma, Y., J. Liu, H. Shi, and L. Yu. 2016. Isolation and characterization of anti-inflammatory peptides derived from whey protein. J. Dairy Sci. 99:6902-6912. https://doi.org/10.3168/jds.2016-11186.

Maeno, M., N. Yamamoto, and T. Takano. 1996. Identification of an antihypertensive peptide from casein hydrolysate produced by a proteinase from Lactobacillus helveticus CP790. J. Dairy Sci. 79:1316-1321. https://doi.org/10.3168/jds.S0022-0302(96)76487 $-1$.

Malinowski, J., M. Klempt, I. Clawin-Radecker, P. C. Lorenzen, and H. Meisel. 2014. Identification of a NFkB inhibitory peptide from tryptic $\beta$-casein hydrolysate. Food Chem. 165:129-133. https://doi .org/10.1016/j.foodchem.2014.05.075.

Mallat, Z., S. Besnard, M. Duriez, V. Deleuze, F. Emmanuel, M. F. Bureau, F. Soubrier, B. Esposito, H. Duez, C. Fievet, B. Staels, N. Duverger, D. Scherman, and A. Tedgui. 1999. Protective role of interleukin-10 in atherosclerosis. Circ. Res. 85:e17-e24. https://doi .org/10.1161/01.RES.85.8.e17.

Marcone, S., K. Haughton, P. J. Simpson, O. Belton, and D. J. Fitzgerald. 2015. Milk-derived bioactive peptides inhibit human endothelial-monocyte interactions via PPAR- $\gamma$ dependent regulation of NF-кB. J. Inflamm. (Lond.) 12:1. https://doi.org/10.1186/ s12950-014-0044-1.

Miller, G. D., J. K. Jarvis, and L. D. McBean. 2006. Handbook of Dairy Foods and Nutrition. 3rd Ed. CRC Press, Boca Raton, FL.

Mizuno, S., K. Matsuura, T. Gotou, S. Nishimura, O. Kajimoto, M. Yabune, Y. Kajimoto, and N. Yamamoto. 2005. Anti-hypertensive effect of casein hydrolysate in a placebo-controlled study in subjects with high-normal blood pressure and mild hypertension. Br. J. Nutr. 94:84-91. https://doi.org/10.1079/BJN20051422.

Mizuno, S., S. Nishimura, K. Matsuura, T. Gotou, and N. Yamamoto. 2004. Release of short and proline-rich antihypertensive peptides from casein hydrolysate with an Aspergillus oryzae protease. J. Dairy Sci. 87:3183-3188. https://doi.org/10.3168/jds.S0022 -0302(04)73453-0.

Moore, C., C. Tymvios, and E. Michael . 2010. Functional regulation of vascular and platelet activity during thrombosis by nitric oxide and endothelial nitric oxide synthase. Thromb. Haemost. 104:342349. https://doi.org/10.1160/TH09-11-0764.

Nakamura, T., K. Hirota, K. Mizushima, Y. Ohki, N. Naito, N. Yamamoto, and T. Yoshikawa. 2013. Milk-derived peptides, Val-Pro-
Pro and Ile-Pro-Pro, attenuate atherosclerosis development in apolipoprotein e-deficient mice: a preliminary study. J. Med. Food 16:396-403. https://doi.org/10.1089/jmf.2012.2541.

Nakamura, Y., N. Yamamoto, K. Sakai, A. Okubo, S. Yamakazi, and T. Takano. 1995. Purification and characterization of angiotensin-I converting enzyme inhibitors from sour milk. J. Dairy Sci 78:777-783. https://doi.org/http://dx.doi.org/10.3168/jds.S0022 $-0302(95) 76689-9$.

Nonaka, A., T. Nakamura, T. Hirota, A. Matsushita, M. Asakura, K. Ohki, and M. Kitakaze. 2014. The milk-derived peptides Val-ProPro and Ile-Pro-Pro attenuate arterial dysfunction in L-NAMEtreated rats. Hypertens. Res. 37:703-707. https://doi.org/10 $.1038 / \mathrm{hr} .2014 .72$.

Rodríguez-Figueroa, J. C., A. F. González-Córdova, M. J. TorresLlanez, H. S. Garcia, and B. Vallejo-Cordoba. 2012. Novel angiotensin I-converting enzyme inhibitory peptides produced in fermented milk by specific wild Lactococcus lactis strains. J. Dairy Sci. 95:5536-5543. https://doi.org/10.3168/jds.2011-5186.

Santiago-López, L., A. Hernandez-Mendoza, B. Vallejo-Cordoba, V. Mata-Haro, and A. Gonzalez-Cordova. 2016. Food-derived immunomodulatory peptides. J. Sci. Food Agric. 96:3631-3641. https:// doi.org/10.1002/jsfa.7697.

Savijoki, K., H. Ingmer, and P. Varmanen. 2006. Proteolytic systems of lactic acid bacteria. Appl. Microbiol. Biotechnol. 71:394-406. https://doi.org/10.1007/s00253-006-0427-1.

Sieuwerts, S., D. Molenaar, S. van Hijum, M. Beerthuyzen, M. Stevens, P. Janssen, C. Ingham, F. de Bok, W. de Vos, and J. van Hylckama Vlieg. 2010. Mixed-culture transcriptome analysis reveals the molecular basis of mixed-culture growth in Streptococcus thermophilus and Lactobacillus bulgaricus. Appl. Environ. Microbiol. 76:7775-7784.

Smeianov, V. V., P. Wechter, J. R. Broadbent, J. E. Hughes, B. T. Rodriguez, T. K. Christensen, Y. Ardo, and J. L. Steele. 2007. Comparative high-density microarray analysis of gene expression during growth of Lactobacillus helveticus in milk versus rich culture medium. Appl. Environ. Microbiol. 73:2661-2672. https://doi .org/10.1128/AEM.00005-07.

Sonestedt, E., E. Wirfalt, P. Wallstrom, B. Gullberg, M. Orho-Melander, and B. Hedblad. 2011. Dairy products and its association with incidence of cardiovascular disease: The Malmö diet and cancer cohort. Eur. J. Epidemiol. 26:609-618. https://doi.org/10 $.1007 / \mathrm{s} 10654-011-9589-\mathrm{y}$.

Sütas, Y., M. Hurme, and E. Isolauri. 1996b. Down-regulation of antiCD3 antibody-induced IL-4 production by bovine caseins hydrolysed with Lactobacillus GG-derived enzymes. Scand. J. Immunol. 43:687-689. https://doi.org/10.1046/j.1365-3083.1996.d01-258.x.

Sütas, Y., E. Soppi, H. Korhonen, E. Syvaoja, M. Saxelin, T. Rokka, and E. Isolauri. 1996a. Suppression of lymphocyte proliferation in vitro by bovine caseins hydrolyzed with Lactobacillus casei GGderived enzymes. J. Allergy Clin. Immunol. 98:216-224. https:// doi.org/10.1016/S0091-6749(96)70245-2.

Tellez, A., M. Corredig, L. Y. Brovko, and M. W. Griffiths. 2010. Characterization of immune-active peptides obtained from milk fermented by Lactobacillus helveticus. J. Dairy Res. 77:129-136. https://doi.org/10.1017/S002202990999046X.

Theodorou, G., and J. Politis. 2016. Effects of peptides derived from traditional Greek yoghurt on expression of pro- and anti-inflammatory genes by ovine monocytes and neutrophils. Food Agric. Immunol. 27:484-495. https://doi.org/10.1080/09540105.2015 .1129598 .

Tidona, F., M. Criscione, A. M. Guastella, A. Zuccaro, S. Bordonaro, and D. Marletta. 2009. Bioactive peptides in dairy products. Ital. J. Anim. Sci. 8:315-340. https://doi.org/10.4081/ijas.2009.315.

Turner, A. J., and N. M. Hooper. 2002. The angiotensin-converting enzyme gene family: Genomics and pharmacology. Trends Pharmacol. Sci. 23:177-183. https://doi.org/10.1016/S0165-6147(00)01994 -5 .

Udenigwe, C. C., and R. E. Aluko. 2012a. Multifunctional cationic peptide fractions from flaxseed protein hydrolysates. Plant Foods Hum. Nutr. 67:1-9. https://doi.org/10.1007/s11130-012-0275-3. 
Udenigwe, C. C., and R. E. Aluko. 2012b. Food protein-derived bioactive peptides: Production, processing and potential health benefits. J. Food Sci. 77:R11-R24. https://doi.org/10.1111/j.1750-3841 2011.02455.x.

Unger, T. 2002. The role of the renin-angiotensin system in the development of cardiovascular disease. Am. J. Cardiol. 89(2A):3-9. https://doi.org/10.1016/S0002-9149(01)02321-9.

Wagar, L. E., C. P. Champagne, N. D. Buckley, Y. Raymond, and J. M. Green-Johnson. 2009. Immunomodulatory properties of fermented soy and dairy milks prepared with lactic acid bacteria. J. Food Sci. 74:M423-M430. https://doi.org/10.1111/j.1750-3841 2009.01308.x.

Wells, J. M. 2011. Immunomodulatory mechanisms of lactobacilli. Microb. Cell Fact. 10(Suppl 1):S17-S31. https://doi.org/10.1186/ 1475-2859-10-S1-S17.

Yamamoto, N. 1997. Antihypertensive peptides derived from food proteins. Biopolymers 43:129-134. https://doi.org/10.1002/ (SICI)1097-0282(1997)43:2<129::AID-BIP5>3.0.CO;2-X.
Yamamoto, N., A. Akino, and T. Takano. 1993. Purification and specificity of a cell-wall-associated proteinase from Lactobacillus helveticus CP790. J. Biochem. 114:740-745. https://doi.org/10.1093/ oxfordjournals.jbchem.a124247.

Yamamoto, N., M. Maeno, and T. Takano. 1999. Purification and characterization of an antihypertensive peptide from a yogurt-like product fermented by Lactobacillus helveticus CPN4. J. Dairy Sci. 82:1388-1393. https://doi.org/10.3168/jds.S0022-0302(99)75364 -6 .

\section{ORCIDS}

J. M. Green-Johnson @ https://orcid.org/0000-0001-7207-2431

H. Jones Taggart (i) https://orcid.org/0000-0002-5234-0854

J. L. Strap @ https://orcid.org/0000-0001-7514-6125 